\title{
The impact of globalisation on human rights
}

\author{
by Olusoji Elias
}

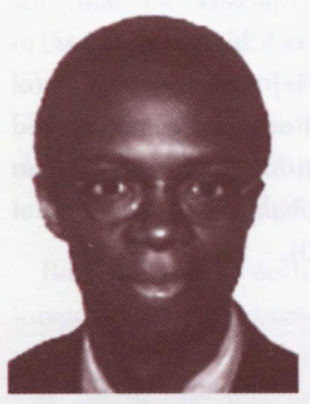

Olusoji Elias

Olusoji Elias considers the latent inter-relationship between two of the most significant and challenging legal issues confronting human society today.

I should probably not be much of a surprise that the concurrent, but discrete, phenomena of globalisation and human rights, as they may be considered as pervasive legal topics of some considerable priority, have in various ways and from different perspectives produced quite a burgeoning corral of legal and related literature, as any bibliographical catalogue inspection will confirm.

This article seeks to explore and explain the inter-relationship between these themes, in order to show how it is that intersections between them are primed, in a pluralistic context and attitude, to be of much significance in the shaping of their worthwhile development.

\section{INTRODUCTION}

Partly because both originate at the end of the last millennium there are many points at which they correspond and indeed are simultaneously interdependent. Both contend with localism, statehood, domestic jurisdiction and ideology, albeit in differing ways and at different levels. They profoundly enjoin and variably evolve cogent legal responses to normative extra-legal considerations from political, sociological, philosophical and other cultural contexts that feature prominently in each of their self-validating schemes of things. They are arguably at their most apparent within regional, or other international organisational spheres. They are perceived to entail different, perhaps equivocal, interpretations depending on the observer's standpoint - sometimes rather like the proverbial elephant and the six blind men. Both involve the question of how formally to surmount structural limitations which exist in the area of justiciability. Each makes fundamental claims to attributes and attractions of dynamism, universalism and relativism and has a common 'post-modernist counterpart' - as well as a foe - in localism and local resistance (see Gunther Teubner (ed.), Global Law Without a State, Dartmouth, 1996, at p. xvii). Both are fraught with interpretive paradoxes deriving from questions of binarism and polarisation, but will each play an enormous role in the legal shape of things to be. They respectively involve multitudinous processes (both statal and non-statal), bear geographical burdens and have convergent high incidence areas,

such as civil society and economic activity. As Andrea Bianchi has argued in 'Globalization of Human Rights: The Role of Non-State Actors' (in Teubner (ed.,) above, at pp. 179-212), true universalisation of legal human rights norms at the global level may likely result as 'the germ of the process of globalisation of human rights law via the dynamics of a transnational civil society'. Globalisation and human rights law respectively manifest an openness of content and of texture.

Points of divergence arising from inherent differences of scopes of influence are rather more profound, and these bring forward a good few of the salient issues. Human rights and their coincident legal aspects perhaps represent one of the most significant features of the contemporary international legal order. The juxtapositive analysis with law-and-globalisation which this article presents should clearly indicate a gap between a much-formalised and maturing human rights law and an informal, and predominantly nascent, so-called 'global law'. The article's theme points to existing and foreseeable possibilities and assists in containing the discussion within the parameters required by the discipline of law. One might say that human rights law is itself global, in scope at least. However, it is of some interest that human rights are not necessarily always construed to be 'global issues' requiring 'global solutions' (cf. Overseas Development Institute, Briefing Paper 1999 (2) July, p. 1 (Box 1)).

In Britain, the last bastion of unencoded individual rights which, paradoxically, led the post-second world war movement that produced the first human rights documents (the United Nations' Universal Declaration of Human Rights (UDHR) 1948 and the European Convention on Human Rights (ECHR) 1950), a Human Rights Act which substantially looks to the latter is set to acquire the force of law. Whether and on what basis this may be ascribed to globalisation is an important question, not least because an affirmative response would refute the unidirectionalism (i.e. that the world order reflects the hegemony of the developed world) that is often characteristic of globalisation discourse, as well as mark the revalorisation of old battle lines in terms that those lines have either been radically redrawn post-cold war or are in modulation in response to new 
norms (e.g., the emergence of sub-categories of exceptionally relevant types of human right: the rights of women and children and those of indigenous populations; conflict management; development-related phenomena; trade liberalisation, the environment and global warming; peace; the resolution of disputes by alternative means) as may be the case.

It is a matter of fact that the ECHR has provided the basis for many human rights codes elsewhere, such as in the Commonwealth. Indeed, the convention was never intended to be local or country-specific. Franck rightly maintains that the diversity of human rights documents collectively permits (as a 'large normative canon') 'all persons to assume shared responsibility for shaping the civil society in which they live and work' (in Fairness in International Law and Institutions, Clarendon, 1995, pp. 123-124).

One recent reminder of what one may call the globalisation of human rights is afforded by the Pinochet affair in the English legal system, where the writ of a local magistrate in Spain could have run as far as the House of Lords had the circumstances - concerning the removal of the medieval conception of absolute immunity for former heads of state in respect of international crimes - made it right for it to have done (cf. Frances Webber, 'The Pinochet Case: The Struggle for the Realisation of Human Rights', 26 Journal of Law and Society 523 (1999), especially at pp. 532-537).

In its widest conceptualisation, globalisation does not definitionally or exclusively address legal issues in human rights but expands to include them. Moreover, contrary to the inherent restrictions that are recognised to accompany the idea of 'global law' (cf. Bianchi, at p. 179), it is neither improperly ambitious nor an exercise in abstraction to refer in this context to the radical aspects of the themes of transnationalism and civil society. These themes have significantly accounted for the substantial progress in the development of international human rights law over the last 50 years or so, without attempting to suggest that there are clear or simple solutions for the taking.

If any truly consequential impact on human rights law is to be discerned to have originated from general or specific global processes properly so-called, then the notion and the role of civil society must be a primary focal point, especially as these processes intersect with central issues of information, in a general sense, and communications. First, the issues from nomenclature, being particularly mindful that elemental concern is with the way in which individual (or generic) human beings are treated by local state law, and how effectively legal internationalism deals with the treatment. In particular, the traditional legal division between matters relating to governance of the public and the private institutions is-increasingly to be seen to fall within the role of civil society.

\section{IMPACT OR INTERPENETRATION?}

The main broad characteristics and attributes of globalisation deserve to be briefly rehearsed. It involves several processes. It is typified by dichotomies, by informality and by binarities between the local and the global. Professor William Twining states authoritatively ('Globalisation and Legal Theory: Some Local Implications' in MDA Freeman (ed.), Current Legal Problems 1996, Clarendon, 1996, at p. 6) that:

in analysing the contemporary world, it is often not enough to focus on the traditional cast of small actors: sovereign states, official international organisations, and individuals ... The concept of legal personality, an old favourite in Austinian analytical jurisprudence, may be ripe for a revival in a global context.'

Professor Anthony Giddens describes globalisation as 'the intensification of worldwide social relations which link distant localities in such a way that local happenings are shaped by events occurring many miles away and vice versa' (The Consequences of Modernity, polity, 1990, at p. 64). The economist had traditionally associated globalisation purely with crossborder economic and financial markets, so that, for example, it is inevitable to enquire, as Chinkin does, as to whether 'economic globalization make[s] concentration upon states' obligations worthless [in a horizontally structured international legal system]?' ('International Law and Human Rights' in Tony Evans (ed.) Human Rights Fifty Years On: A Reappraisal, Manchester, 1998, at p. 120).

\section{ULTIMATE GOAL}

Today, there is an extensive diversification of issues that are brought under the umbrella of human rights, and 'human rights' themselves have commendably evolved from their primarily political origins as first generation human rights to being fully-fledged creatures of the law...They are enforceable in the courts, they attract sanctions in the event of breach, they are the subject of concerted efforts to make them more articulate. The ultimate goal is human accountability in the face of expansionist developments and trends, new issues and connections which predominantly centre, as they should, on people and governance.

In much the same vein of 'the possibility of delivering economic and social rights within the prevailing liberal economic structure' (in 'International financial institutions and social and economic rights: an exploration', in Evans, op. cit., at p. 161), Thomas observes, as part of her description of globalisation as 'the process whereby power is located in global social formations and expressed through global networks rather than through territorially based states' (p. 162), that:

' $\mathrm{t}]$ he process of globalization is rendering it impossible for many states to exercise a basic minimum control over the domestic economy, and therefore it is directly undermining the state's ability to deliver social and economic rights to citizens'. (at p. 163, citing J Mittelman (ed.), Globalization: Critical Reflections, Rienner, 1995.)

She concludes that:

'resistance to the orthodoxy increases across the globe, as social movements arise to protest against the universalization of essentially western values of economic and political liberalism and accompanying western conceptions of human rights.' (p. 183)

People are clearly now to be seen at the centre of the globalisation of good governance, especially when it is convened to form what is loosely known as civil society, hence the assertion 'the emergence of global civil society.' This is not to overrate the notional value of 'civil society', fraught as it is with considerations of its being hegemonistic, for example. Rather, it becomes reasonable to anticipate the expansion of economic and social rights from their relatively better-exercised civil and political counterparts. 
The Commission on Global Governance begins its report (Our Global Neighbourhood, OUP, 1995, at p. 1) with the observation that:

'[t]he collective power of people to shape the future is greater now than before, and the need to exercise it is more compelling'.

It goes on to assert (at p. 62) that:

'[t]he emergence of a global civil society is an important precondition of democracy at the global level, although it cannot guarantee it'.

(See also, e.g., the Report of the UN Secretary-General on the Work of the Organisation, $\mathrm{A} / 48 / 1,10.9 .93$, at p. 5.) The Commission firmly places human rights within the framework of global security (at p. 79) and recognises the potential for enhancing universally human rights via trade-restricting measures (at p. 170).

But what may accurately and usefully be made of the foregoing for the present purpose, beyond holding that all aspects of human life with which human rights discourse would run are in one way or another subject or to be subject to globalisation? Globalisation is ostensibly asymmetrical, and is subject to geographical and other circumstantial limits and burdens. Of itself, it does not have aims but, rather, is to be seen as ineluctable (cf. Batou, 'Is Globalisation Ineluctable?', (an unpublished conference paper, 1999). It is to be appraised from its tangible consequences. It thrives outside state sovereignty but its formalism, if any, depends on the mutuality of its non-state agents' interaction with statehood. Inevitably, it poses possibly more questions than it provides practical solutions to peoples' problems. It is not directly concerned with development, however described, in relation to human rights. But it must deal with the issues in a pluralistic context.

With an eye to the developing world, it has to be said that the informalistic character of the notion of 'global law' has much to commend it (see, e.g., O Elias, 'Globalization, 'Law and Development', and Contemporary Africa' [2000] EJLR). As part of the global process, the cultivation of a truly responsive civil society would directly respond to the development-based requirements of material development, to humanisation, and other firm cultural foundations necessary at the local level, without underestimating cultural diversity and differentiation in national, international and global contexts. In fact, it is the task of producing worthy local norms, which adequately reflect and substantiate internationallyderived human rights codes' versions of these norms, that hallmarks any real impact from cultural globalisation on the law on human rights. Local norms at issue must include, for example, the prioritisation of the civil entitlements of women, those deriving from religion, from multiparty democracy, all of which are necessary preconditions of good governance.

Banda provides an important analysis in 'Global Standards: Local Values' (1999-2000, forthcoming). In the illuminating context of how the issue of global standards and local values is mediated using the customary family law of patrilineal societies in Africa, she argues that:

\section{given the highly contested nature of the legitimacy of global} standards at the local level and indeed the multifaceted nature of "local values", mediating the two will not be an easy task ... [i] ndeed the power differentials between men and women, elders and younger people, ethnicities, religious groupings, make it clear that getting a coherent set of values with which to test global standards is in itself one of the main challenges.'
The North-South divide presents perhaps the most consequential benchmark as to impact if one is to avoid a monocular or territorially-narrow view of the global process (cf. Judge Rosalyn Higgins, Problems and Process: International Law and How We Use It, Clarendon, 1994, pp. 96-97)). Multiplicities and complexities strengthen the argument for pluralism, over and above binarism, if civil society is to be truly global and effective.

A more forceful advocate of the pro-globalisation ethic could argue that 'global law' is in reality more than a latent complement to formal (international human rights) law, that it is a living subphenomenon and not merely an amorphous contingent alternative, and that it.indubitably has its own Dworkinian legal integrity founded in a quite divergent pluralist context. To be clear, $\mathrm{R} A$ Wilson is of the view that the human rights movement is to be seen as 'one of the most globalised political values of our time' (in the introduction to his (ed.) Human Rights, Culture and Context: Anthropological Perspectives, Pluto, 1996, p. 1), replacing the communist/capitalist ideologies of the cold-war era and embracing the programmatic universalism of UDHR principles.

From its inception in the post-second world war years, the development of human rights law up to the present reveals a natural and persistent dynamism that has made answerable, or has at least credibly sought to make so, the problems that have provoked humanist counteraction. The UDHR itself was brought into being as a direct result of the atrocities of that war. Today, there is an extensive diversification of issues that are brought under the umbrella of human rights, and 'human rights' themselves have commendably evolved from their primarily political origins as first generation human rights to being fullyfledged creatures of the law (cf. art. 22, African Charter, on the 'legal' right to development). They are enforceable in the courts, they attract sanctions in the event of breach, they are the subject of concerted efforts to make them more articulate. The ultimate goal is human accountability in the face of expansionist developments and trends, new issues and connections which predominantly centre, as they should, on people and governance.

\section{PRACTICAL ISSUES}

questions of actual enforcement and procedural methodology, rather than those of standard-setting for example, are today's real practical issues.

Unavoidably, the questions which must be asked include whether globalisation, literally or technically, has impacted on human rights law, whether human rights themselves likewise affect the global process, and whether the reality is that we are in fact concerned with disparate streams in a much broader scenario in which there are many other factors deserving to be taken on board - such as the reduction of the gap or friction between state and interpersonal spheres of activity in which these issues also necessarily feature (for example, in the context of the recognition of legal liability or responsibility of non-state actors). W H Reinicke writes of an emerging global public policy (Global Public Policy, Brookings Institution 1998), in which individual rights and entitlements form one of several focal points. The net effect is that the relationship between human rights and globalisation is best appraised from observable consequences. Human rights have undoubtedly been promoted to, and proliferated, at the global level at which the idea of truly 
worldwide civil society is not remotely unreal; rather, it is more a conflict as to which right is at issue and at whose behest. Higgins's articulation of this issue, particularly as to proliferation, is characteristically sophisticated:

'Thus it is that we now have an unprecedented ratification rate for a treaty on the rights of the child, whereas a decade ago there would have been serious doubt that there was any such human right. In principle, therefore, the list could be infinite. In practice, the continued expansion of the list of rights presents problems. If states accede to this expansion for reasons of convenience, rather than conviction, then the coinage will undoubtedly become debased, and the major operational importance of designating a right a human right - that opprobrium attaches to ignoring it - will be lost .

The prime task is necessarily the identification and articulation of the right.' (op. cit., p. 105)

(On the issue of ratification in African countries, see F Banda 'Meaningless Gestures? African Countries and the Convention on the Elimination of All Forms of Discrimination Against Women' in J Eekelaar and T Nhlapo (eds.), The Changing Family, Hart, 1999, 529ff.).

It is of course true that regionalist and other theme-based discourse bears out a certain truism: that there is usually a prototype, matrix or blueprint from one region (typically Europe) to be adapted or otherwise emulated there or elsewhere, as witness the various regional human rights structures. Likewise, it cannot seriously be countermanded that human rights and global processes share a common horizon, namely the improvement (not at all necessarily the uniformisation) of the quality of human life everywhere. But the consistent leveller is that revalorising the local often requires a deliberate normativisation, a process of transformation or relinquishment of what has come before, that it is not merely a matter of global harmonisation for its own sake. To say that there are huge enigmas of compatibility is to underscore the nature of the beast in these respects. So it is that questions of actual enforcement and procedural methodology, rather than those of standard-setting for example, are today's real practical issues. And globalism plays an important part in terms of both the necessity for humanist response in the first place and the means by which that response is to be made to count, be it in the form of rights' definition, of evidential fact-finding and substantiation, or of ideological institutionalisation. States and civil society, tritely, must consciously collaborate in a pluralist way that re-addresses their respective attitudes in the face of shared humanistic ideals. To provisionally conclude, as Chinkin does (loc. cit, at pp. 121-122):

the capability of the international legal system to be relevant to human rights requires dislodging legal and conceptual boundaries between, for example, human rights law and international economic law, between international humanitarian law and military necessity, between law and non-law and between states and non-state actors. The understanding of rights must be more relevant to those whose interests are largely excluded from its scope and to those non-state actors that remain outside its formal constraints. This requires a continual process of redefinition of the traditional scope of human rights law that goes beyond inequality, or even specific issues such as racial, gendered or ethnic violence. It also requires rethinking the primary role of the state in guaranteeing human rights in light of global forces that limit its freedom of internal choice. These phenomena must be analysed in their entirety to reveal the multiplicity of disadvantage and addressed in their wider political, economic and social contexts. Non-compulsory legal regulation cannot achieve such fundamental restructuring of power but it nevertheless has its role in the process.

\section{ADVANCEMENT AND PARADOX}

It must go without saying that there is a highly ramified interrelatedness between globalisation and human rights, if not necessarily between globalisation and human rights law. This preferable view accommodates the proposition that the former unavoidably impacts upon the latter at the general level. But the heterogeneity of the respective streams makes it either less facile or simply myopic to hold that the field of consideration is served well enough by looking at the effects of the former upon the latter, rather than in both directions. Indeed, to ascribe 'impact' literally to human rights discourse would be concerned with tangible ephemera and not with the underlying complex processes and solutions involved. State sovereignty, we are convincingly told (see N MacCormick, 'Beyond the Sovereign State' 56 MLR 1 (1993)), is much eroded, be this consequent upon the global process (relative irrelevance of physical boundaries; human and cultural transmigration; multinational corporate activity) or on other (related) factors like regionalism. There is much that is ambiguous and uncertain (cf. K Mills, Human Rights in the Emerging Global Order: A New Sovereignty?, MacMillan, 1998, e.g. at p. 53).

A most fundamental issue concerns what is to replace eroded states. Will the scope of humanitarian intervention, for example, become an obligated response rather than one that turns on power? The intersection between globalisation and human rights triggers a good deal more and, more importantly perhaps, necessitates an enlargement of the lawyer's usual human rights discipline as, doubtless, the upcoming applications of the UK's Human Rights Act may reveal. Evolution of further concomitant legal rights are not to be ruled out, especially at the national or local level, possibly outwith the liberating undertones of public-sphere human rights law - as witness the debate surrounding the traditional dichotomy between public legal rights and those sourced in private law (see the Rt Hon Sir Richard Buxton, 'The Human Rights Act and Private Law', 116 LQR 48 (2000), especially at p. 59: 'The Act ... may have a more tangential effect on private law litigation ...').

Human rights law - as customary international law concerned with the rule of law, with sociological jurisprudence and with civil society - is indeed global law. All that could be given to differentiate them is the issue of how narrowly one construes law as a valid and effective phenomenon. Somewhat paradoxical though it may seem, it is to human rights law that a foreign investor must look for the protection of its rights, for example, to just compensation (cf. the Fourth, Fifth, Seventh and Fourteenth Amendments to the US Constitution; see the Supreme Court decision in Lynch v Hounslow Finance Corporation 405 US 538 (1972), especially at p. 552: 'a fundamental interdependence exists between the personal right to liberty and the personal right to property. Neither could have meaning without the other'). Paradoxically, there is cause for surprise that a human right to property has not attracted much consideration in international law; it does not feature in either the International Convention on Economic, Social and Cultural Rights or in the International Convention on Civil and Political 
Rights (cf. Lithgow v UK 102 ECHR (Ser. A) 8 EHRR 329 (1980)). Furthermore, as Franck points out:

'the increase in individuals' human rights is inevitably accompanied by an increase in their responsibility for human wrongs, even when committed under the colour of state.' (op. cit., at p. 264)

And this is to be construed in the context of the symbiosis subsisting between human rights and globalism.

At a different level, relating to concepts and jurisprudential distinctions, one writer has observed that:

'[d]istinguishing development law questions from private international law questions may not be easy, since implications of both may be present in any given fact scenario'. (R Sarkar, Development Law and International Finance, Kluwer, 1998, at p. 50)

He illustrates thus (at p. 51)

'whether women should have the right to the legal custody of their children following a separation from the marital domicile may pose a family law issue under domestic law, or an international human rights question, or, if legal reform of existing family law is contemplated in order to change the legal status of women, a development law question.

Indeed, he finds that the effects of economic globalisation are themselves undiscriminatingly global, albeit in often radically different ways. Kellner had shown that cultural homogenisation, the bane of neo-Marxists, traditionalists, multiculturists, and environmental protectionists, was a significant factor in these regards (Globalization and the Postmodern Turn, at p. 2). Inevitably, law is a medium, having enormous potential, within reason, for the expression of the diversified culture of today.

\section{CONCLUSION}

Legal human rights depend, first and foremost, on an empowered legal process: courts' diligence; claimants' access to justice, to information and evidence; a compliant general attitude. It is fairly obvious that the contemporary conventional nature of human rights discourse, by which the dynamics thereof are emphasised, provides a natural template for making the most of the symbiosis with the (more) powerful forces of globalisation. Precisely how this is to be achieved is neither a matter for conjecture nor a forgiving exercise as the complexity and diversity of the issues involved have shown. And statehood is here to stay. The role of civil society and communication in bringing about desirable improvements has not gone unremarked, while the ever-increasing incidence of transnationalism has been a frequent over-riding factor. Whatever the observer's standpoint as to human rights and globalisation, a result-oriented attitude is required in order necessarily to avoid retarding the course of things. Solutions to the problems of the one are replete in the mechanisms of the other, and these solutions necessarily are more important.

\section{Olusoji Elias \\ Member of the International Bar Association}

This article is based on an invited seminar presentation at the Human Rights Unit of the Legal and Constitutional Affairs Division, Commonwealth Secretariat, London (July 1999).

The writer acknowledges the useful comments of Dr F Banda in the course of preparing the present draft.

\section{Doing Business in Europe}

Doing Business in Europe is an easy-to-follow guide to European tax and legal systems. It is an ideal first port of call for companies and their advisers operating or planning to operate across Europe or in particular jurisdictions.

\section{Your subscription includes}

- Loose-leaf - 2 volumes updated 6 times a year covering key western European countries

- Newletter - European Newletter, 10 issues a year, and Eastern European Newletter*, issued monthly *The Eastern European Newletter is also available as a separate subscription

\section{Key benefits}

- Easy-to-use - standard template in the loose-leaf makes country-by-country comparisons easy.

- Up-to-date - frequent updating and regular newsletters provide the latest information on western and eastern European developments.

- Authoritative - combined with CCH.New Law's own expertise, the authors are from leading firms of lawyers and accountants dealing with the specific countries covered.

- Accessible - comprehensive topic indexing provides ready access to the text.

- Wide reaching - each country division contains broad coverage of various subjects, e.g. tax, company law, employment law and competition. 